\title{
Water Footprint Evaluation of Oil Palm Fresh Fruit Bunches in Pathumthani and Chonburi (Thailand)
}

\author{
J. Mungkalasiri, R. Wisansuwannakorn, and W. Paengjuntuek
}

\begin{abstract}
Due to an encouragement of renewable energy, an implantation of oil palm in Thailand is increased. It affects the amount of water consumption in each area. From this point, the aim of this work is to evaluated water footprint (WF) of oil palm fresh fruit bunches using CROPWAT program. The water footprint assessment of fresh fruit bunches in Pathumthani and Chonburi provinces are comparatively studied finding the suitable plantation area in term of water availability. In addition, the appropriate blue water footprint calculation methods and weather data sources are evaluated. The results revealed that Chonburi is more suitable plantation area than Pathumthani. In addition, the results from this study can be used as a water management approach for sustainable agriculture.
\end{abstract}

Index Terms-Oil palm fresh fruit bunches, water footprint, water management.

\section{INTRODUCTION}

At present, the promotion of bio-based renewable energy is politically and economically support by government. Palm oil is one of the promising plants because of its efficiency and a long run profit compare to others (e.g. rice, orange). Oil palm tree could produce palm oil up to $18 \mathrm{ton} / \mathrm{ha}$, which is about 10 times higher than soybean and also the low costs of oil production per $\mathrm{kg}$ less than other vegetable oils. The investment and return seem to be more realistic to farmers. The major area of oil palm located in the southern of Thailand because a high rate of precipitation. However, the current has expanded to other regions e.g. northern, northeast or even the central lowlands and is likely to progressively increasing [1]. The oil palm plantation in the central area mostly plant in Pathumthani province (especially in irrigated area). In this place, oil palm produce a high yield because a very complete water irrigation system with the ditches. In the past, this location was appropriate to orange farm. And Pathumthani also has a river running through. It makes a complete irrigation system. This comportment is different to oil palm plantation in southern which is mostly depended on rainfall. In eastern areas of the country were planted oil palm

Manuscript received June 10, 2014; revised August 7, 2014

W. Paengjuntuek is with Chemical Engineering, Faculty of Engineering, Thammasat University. Klong 1, Klong Luang, Pathumthani 12120 Thailand (e-mail: pworanee@engr.tu.ac.th).

J. Mungkalasiri and R. Wisansuwannakorn are with Life Cycle Assessment Lab, National Metal and Materials Technology Center, 114 Paholyothin Rd., Klong 1, Klong Luang, Pathumthani 12120 Thailand (e-mail: jitti.mungkalasiri@nstda, ruthairw@mtec.or.th). as well. Chonburi province is an area that has grown the most in the East. The oil palm plantation management employs almost the same criteria in the south.

Water is very important factor in the cultivation. It is necessary to consider the amount of water used in the implementation of activities. More than 71 percent of Earth's surface is covered by water. However, 97.5 percent is salty and only 1.75 percent is fresh water. Unfortunately, one part is trapped in the form of snow and ice. Remaining water is available less than 1 percent [2]. Therefore, water should be recognized the importance of using efficiently and for maximum benefit. This is a reason that water footprint is intervened as a common tool to measure water consumption both directly and indirectly to reflect real amount of water consumption in goods and services of human activities. This will help to understand the problem of water shortage and pollution. As well as lead to solutions linked to production processes and supply chain. Water Footprint is expressed in terms of the amount of water used per functional unit [3].

Currently, Thailand has realized the impact of water scarcity. Make researches evaluate water footprint in several product categories, such as the production of ethanol from cassava [4], sugarcane and cassava-based bio-ethanol [5]. For oil palm products [6] have studied the water footprint of planting oil palm in northern and southern of Thailand. Results showed that the northern areas consume up to 3.9 times compare to the southern area. Phitsanulok Province, the most water used, consumes 6,098 cubic meters per metric ton fresh fruit bunches (FFB). And Surat Thani provinces have a lowest result which is equal to 1,070 cubic meters per metric ton FFB. The main reason is geographical and climatically context [7]. Thus, this research aims to study the water footprint of FFB in Pathumthani (Central) and Chonburi (Eastern). The both sites are not only different in climate and geographic but also the farm managements with irrigation system. Watersheds will be considered to demonstrate the use of water in each area. And finally, compare the suitability of oil palm cultivation.

\section{WATER FOOTPRINT}

A water footprint is a way of assessing potential environmental impacts related to water [8]. In recent years the issue of water use and management has become increasingly central to the global sustainability debate. This increased interest has been driven by growing water demand, increasing water scarcity in many areas and degradation of water quality. This drives the need for a better understanding of water use as the basis of improved water management at local, regional, and global levels [9]. Water footprint concept 
was first introduced by Hoekstra (2002). It calculates the total fresh water use throughout the life cycle or scope in both direct and indirect use [3]-[8]. It can be expressed in various units such as mass (per ton or $\mathrm{kg}$ ), time (per hour or year), energy (joule) and even crop (per piece of crop). The water footprint is aggregated from three classifications; blue water footprint, green water footprint and grey water footprint where each classification has its own calculation for specific data. Green water footprint calculates the evaporation of rainwater in an area during crop growth. Similarly, blue water footprint calculates the evaporation of surface and groundwater in an area during crop growth. However, grey water footprint calculates the volume of water used to assimilate the waste water based on ambient water quality standards. The summation of these three components results in the water footprint of a single product [3].

\section{A. Direct Water Footprint}

This consists of green, blue and grey water footprint components.

First step: Calculate green and blue components from CROPWAT 8.0 model from Eq. (1) and Eq. (2).

Green water footprint:

$$
\mathrm{CWU}_{\text {green }}=10 \times \sum_{d=1}^{\operatorname{lgp}} \mathrm{ET}_{\text {green }}
$$

where

CWU: crop water usage $\left(\mathrm{m}^{3} / \mathrm{ha}\right)$

ET $_{\text {green }}$ : crop evapotranspiration under standard conditions (ETc) obtained from the calculation in CROPWAT model $(\mathrm{mm} / \mathrm{dec})$

lgp: length of growing period that the crop grows.

10: multiplication factor to convert CWU unit from $\mathrm{mm} / \mathrm{dec}$ to $\mathrm{m} 3 / \mathrm{ha}$

Blue water footprint:

$$
\mathrm{CWU}_{\text {blue }}=10 \times \sum_{d=1}^{\lg \mathrm{p}} \mathrm{ET}_{\text {blue }}
$$

where

CWU: crop Water Usage $\left(\mathrm{m}^{3} / \mathrm{ha}\right)$

ET $_{\text {blue: }}$ the difference between total ETc and effective rainfall (Peff) or Irr. Req. in CROPWAT model (mm/dec)

lgp: length of growing period that the crop grows.

10: multiplication factor to convert CWU unit from $\mathrm{mm} / \mathrm{dec}$ to $\mathrm{m}^{3} / \mathrm{ha}$

Second step: Calculate green and blue W.F. from Eq. (3) and Eq. (4).

$$
\begin{aligned}
W_{\text {green }} & =\frac{C W U_{\text {green }}}{\mathrm{Y}} \\
W_{\text {blue }} & =\frac{C W U_{\text {blue }}}{\mathrm{Y}}
\end{aligned}
$$

where

CWU: Crop water usage for green and blue components $\left(\mathrm{m}^{3} / \mathrm{ha}\right)$
Y: yield (kg/ha)

Third step: Grey water footprint is calculated for growing crop by multiplying the chemical application rate by the leaching run-off fraction and dividing by maximum acceptable concentration minus natural concentration for the pollutant considered. Then divide everything by the crop yield as shown in Eq. (5).

Grey water footprint:

$$
\mathrm{WF}_{\text {grey }}=\frac{\left[\alpha^{*} \mathrm{Appl}\right] /\left[c_{\max }-c_{\text {nat }}\right]}{\mathrm{Y}}
$$

where

$\alpha$ : leaching fraction

Appl: fertilizer application rate $(\mathrm{kg} / \mathrm{rai} / \mathrm{yr})$

$c_{\text {max }}$ : maximum allowable concentration $(\mathrm{mg} / \mathrm{L})$

$c_{\text {nat }}:$ natural background concentration $(\mathrm{mg} / \mathrm{L})$

$\mathrm{Y}$ : yield $(\mathrm{kg} / \mathrm{rai} / \mathrm{yr})$

\section{B. Indirect Water Footprint}

Indirect water footprint from fertilizers can be retrieved from SimaPro 7.3.2 database with $\mathrm{ReCiPe}$ point $\mathrm{H}$, whereas the type of fertilizers and pesticides are obtained from Office of Agricultural Economics (2003) and electricity usage from A. D. Martin (2012) [10].

\section{Water Footprint}

Finally, sum everything to get the water footprint in Eq. 6

$$
\mathrm{WF}_{\text {proc }}=\mathrm{WF}_{\text {green }}+\mathrm{WF}_{\text {blue }}+\mathrm{WF}_{\text {grey }}+\mathrm{WF}_{\text {indirect }}
$$

\section{METHODOLOGY}

This study employs CROPWAT 8.0 to evaluate green and blue water of oil palm plantation [11] with combination of two major climate data: (1) department of meteorology and (2) CLIMWAT 2.0. The idea is to analyze the sensitivity of data source for the same province.

In the calculation, the data relate to plant and soil play relevant roles. The source of the data used in the study came from the provincial agriculture office and oil palm plantation (Table I). They provide valuable information to support this study (e.g. root length, critical depletion, yield, plant height, soil type, fertilizer and irrigation system). As well as the crop coefficient $\left(K_{c}\right)$ [12].

TABLE I: INVENTORY FOR OIL PALM PLANTATION IN PATHUMTHANI AND CHONBURI

\begin{tabular}{lll}
\hline \hline Information & Pathumthani & Chonburi \\
\hline \hline Species & Tenera & Tenera \\
Type of soil & Black clay & $\begin{array}{l}\text { Sandy loam } \\
\text { Irrigation water }\end{array}$ \\
$\left(\mathrm{m}^{3} / \mathrm{ha} / \mathrm{y}\right)$ & 31,500 & 406 \\
Fertilizers & & \\
$(\mathrm{N}-\mathrm{P}-\mathrm{K}: \mathrm{kg} / \mathrm{ha} / \mathrm{y})$ & $13-6-27: 143$ & $21-0-0: 144.38$ \\
Yield (ton/ha) & & $0-0-60: 495$ \\
\hline \hline
\end{tabular}

The local data used in this study is the year 2010 in Pathumthani and Chonburi. It consists of maximum and minimum air temperature, relative humidity, wind speed, sunny period per day and precipitation during the period of plant growth (Table II). 
TABLE II: METEOROLOGICAL INFORMATION FOR PATHUMTANI AND CHONBURI IN 2010

\begin{tabular}{|c|c|c|c|c|c|c|c|c|c|c|c|c|}
\hline \multirow[t]{2}{*}{ Month } & \multicolumn{2}{|c|}{ "Min temp. $\left({ }^{\circ} \mathrm{C}\right)$} & \multicolumn{2}{|c|}{ Max temp. $\left({ }^{\circ} \mathrm{C}\right)$} & \multicolumn{2}{|c|}{ "Humidity (\%) } & \multicolumn{2}{|c|}{$\begin{array}{c}\text { Wind speed } \\
(\mathrm{km} / \text { day })\end{array}$} & \multicolumn{2}{|c|}{ Sunny/day (hr) } & \multicolumn{2}{|c|}{$\begin{array}{l}\text { Precipitation } \\
(\mathrm{mm})\end{array}$} \\
\hline & $\mathrm{Pa}$ & $\mathrm{Ch}$ & $\mathrm{Pa}$ & $\mathrm{Ch}$ & $\mathrm{Pa}$ & $\mathrm{Ch}$ & $\mathrm{Pa}$ & $\mathrm{Ch}$ & $\mathrm{Pa}$ & $\mathrm{Ch}$ & $\mathrm{Pa}$ & $\mathrm{Ch}$ \\
\hline Jan & 22.9 & 20 & 32.6 & 34.2 & 73 & 73 & 2.5 & 2.6 & 7.0 & 7.4 & 23.2 & 45.5 \\
\hline Feb & 24.8 & 24.5 & 34.7 & 34.4 & 74 & 76 & 3.2 & 3.7 & 7.0 & 8.7 & 5.3 & 39.0 \\
\hline Mar & 24.9 & 22.4 & 36.3 & 37.3 & 66 & 68 & 3.9 & 3.9 & 7.0 & 7.0 & 4.3 & 19.1 \\
\hline Apr & 26.4 & 24.2 & 37.5 & 37.7 & 67 & 70 & 4.7 & 3.9 & 8.0 & 8.8 & 51.5 & 15.6 \\
\hline May & 26.8 & 24.6 & 36.7 & 39 & 74 & 74 & 4.0 & 2.2 & 8.0 & 6.5 & 100.6 & 132.7 \\
\hline Jun & 26.5 & 24 & 35.4 & 36.4 & 76 & 75 & 4.2 & 1.9 & 8.0 & 5.4 & 234.1 & 132.7 \\
\hline Jul & 25.9 & 24.7 & 33.6 & 35.5 & 79 & 77 & 3.5 & 1.5 & 9.0 & 4.5 & 228.2 & 191.0 \\
\hline Aug & 25.3 & 23.9 & 33.1 & 34.6 & 81 & 80 & 3.2 & 1.7 & 8.0 & 4.5 & 226.3 & 249.6 \\
\hline Sep & 25.5 & 23.9 & 33.4 & 35.2 & 82 & 80 & 2.4 & 1.5 & 8.0 & 5.2 & 535.6 & 247.1 \\
\hline Oct & 25.2 & 21.4 & 31.6 & 34.6 & 81 & 80 & 2.3 & 2.4 & 8.0 & 4.4 & 223.9 & 300.7 \\
\hline Nov & 24.0 & 21.6 & 32.2 & 35.7 & 67 & 65 & 2.9 & 5.0 & 8.0 & 6.2 & 0.0 & 0.0 \\
\hline Dec & 22.7 & 19 & 32.1 & 34.5 & 70 & 67 & 2.8 & 3.3 & 7.0 & 7.2 & 39.8 & 3.4 \\
\hline
\end{tabular}

$\mathrm{Pa}=$ Pathumthani and $\mathrm{Ch}=$ Chonburi

For the indirect water, SimaPro 7.3.2 is used to evaluate the indirect water footprint from the necessary components in the oil palm plantation.

\section{RESUlTS AND DisCUSSION}

This research evaluates the study water footprint of oil palm in Pathumthani and Chonburi. Three issues in comparative studies are shown in the following.

\section{A. Water Footprint Evaluation of Fresh Fruit Bunches by Using Local Climate Data}

This research mainly employs CROPWAT 8.0 to determine crop water requirement (CRW). The interface requires climate and geographical information such as temperature, precipitation, relative humidity, wind speed. The Table III shows the water footprint in year 2010 for each province. The raw data was reported by department of meteorology

TABLE III: WATER FOOTPRINT FOR GREEN, BLUE AND GREY PER TON FRESH FRUIT BUNCHES OF PATHUMTHANI AND CHONBURI

\begin{tabular}{cccrrr}
\hline \hline Area & \multicolumn{3}{c}{ Direct WF $\left(\mathrm{m}^{3} /\right.$ ton $)$} & \multicolumn{1}{c}{$\begin{array}{c}\text { Indirect WF } \\
\left(\mathrm{m}^{3} / \text { ton }\right)\end{array}$} & \multicolumn{1}{c}{$\begin{array}{c}\text { WF } \\
\left(\mathrm{m}^{3} / \text { ton }\right)\end{array}$} \\
\hline \hline $\mathrm{Pa}$ & 423.77 & 162.53 & 92.22 & 0.32 & 678.84 \\
$\mathrm{Ch}$ & 635.65 & 302.70 & 131.96 & 0.34 & $1,070.65$ \\
\hline \hline
\end{tabular}

It was found that the water footprint of palm oil in Chonburi Province $\left(1,070.65 \mathrm{~m}^{3} /\right.$ ton FFB) is higher than Pathumthani $\left(678.84 \mathrm{~m}^{3} /\right.$ ton FFB), two main reasons can explain the result which are the yield (Table I) and annual precipitation (Table II) and. The green and blue water depend on mainly climate condition. However, it was also found that grey water is still high in Chonburi. This value based on farm management (fertilizers and others). The indirect water footprint has little impact on the total. This high precipitation and high yields has lower water footprint compare to low precipitation and low yields, respectively.

\section{B. Comparison of the Water Footprint of Fresh Fruit}

Bunches. Using Weather Data from CLIMWAT

A further study to show in case that researcher has not any data from local. The CLIMWAT 2.0 could provide necessary information to support CROPWAT. The Table IV shows the water footprint of FFB. The impact of CLIMWAT data will influence only green and blue water. The grey is independent from this test.

TABLE IV: WATER FOOTPRINT FOR GREEN, BLUE AND GREY PER TON FRESH FRUIT BUNCHES OF PATHUMTHANI AND CHONBURI. (CLIMWAT 2.0

\begin{tabular}{cccccc}
\hline \multicolumn{5}{c}{ DATA $)$} \\
\hline \hline Area & Green & $\begin{array}{c}\text { Direct WF } \\
\left(\mathrm{m}^{3} / \text { ton }\right) \\
\text { Blue }\end{array}$ & Grey & $\begin{array}{c}\text { Indirect } \\
\text { WF } \\
\left(\mathrm{m}^{3} / \text { ton }\right)\end{array}$ & $\begin{array}{c}\text { WF } \\
\left(\mathrm{m}^{3} / \text { ton }\right)\end{array}$ \\
\hline \hline $\mathrm{Pa}$ & 521.83 & 240.47 & 92.22 & 0.32 & 845.84 \\
$\mathrm{Ch}$ & 718.10 & 317.60 & 131.96 & 0.34 & $1,168.00$ \\
\hline \hline
\end{tabular}

$\overline{\mathrm{Pa}}=$ Pathumthani and $\mathrm{Ch}=$ Chonburi

Results show similar trend compare to the previous study. Chonburi $\left(1,168 \mathrm{~m}^{3} /\right.$ ton FFB) still has higher footprint to Pathumthani (845 $\mathrm{m}^{3} /$ ton FFB). Water footprint in Pathumthani has a significant gap when match up with 678.84 (Table III). It relates directly to data, However, Chonburi has almost the same result. CLIMWAT 2.0 contains low sensitivity in term of liability. It average weather data during 1971 to 2000. This is different from previous study. Therefore, the selection of weather information is critical factor that influence water footprint.

C. Water Footprint Evaluation of Fresh Fruit Bunches by Using Local Climate and Primary Irrigation Data

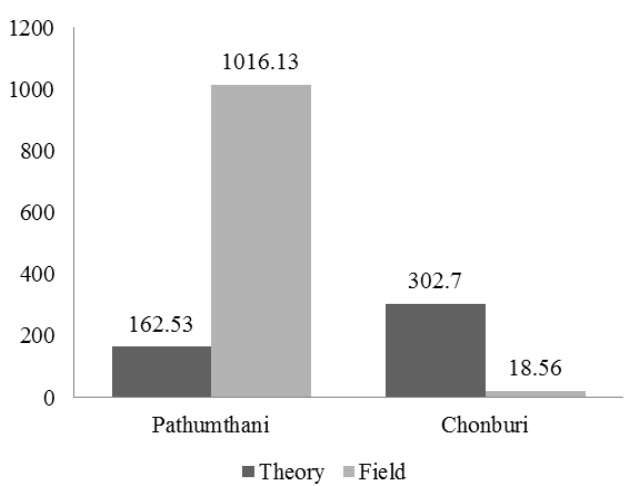

Fig. 1. Blue water (m3) per ton fresh fruit bunches of Pathumthani and Chonburi (Theory and field). 
In this case, we focus on the blue water with represent amount of irrigation water should be provided to the plant. In the real situation farmer may provide or not depend on local situations (the blue water is very relevant indicator to link with water scarcity in river basin). Then compare the result from theory and field data (Fig. 1.).

Results of the study showed that the irrigations are completely different from theory to field. The estimation for Pathumthani is lower $\left(162.53 \mathrm{~m}^{3} /\right.$ ton FFB) compare the real situation (1016.13 $\mathrm{m}^{3} /$ ton FFB). Farmers supply a huge amount of water not only for irrigation but also to retain the water level of ditch, in some case the by-product of the oil palm plantation is fish. This irrigation water came direct for the local dam. The natural resource flow is permanently controlled. In the past and present, this province is very famous to produce jasmine rice and orange. Nowadays, some changes mainly to oil palm oil economical reason and human load intensity.

On the other hand, Chonburi farmer could not afford enough water $\left(18.56 \mathrm{~m}^{3} /\right.$ ton $\left.\mathrm{FFB}\right)$ to reach the requirement $\left(302.7 \mathrm{~m}^{3} /\right.$ ton FFB). Most of the water used in agriculture is rain water. However, the palm is still keeping produce.

Table V shows the recalculated water footprint for Pathumthani and Chonburi with consideration of the real water supply for farm management. Surprisingly, Pathumthani become more water intensive than Chonburi in term of volume (1532.44 to $786.51 \mathrm{~m}^{3} /$ ton FFB).

TABLE V: RECALCULATED WATER FOOTPRINT BY USING WATER IRRIGATION FOR BLUE WATER

\begin{tabular}{|c|c|c|c|c|c|}
\hline \multirow[t]{2}{*}{ Area } & \multicolumn{3}{|c|}{$\begin{array}{c}\text { Direct WF } \\
\left(\mathrm{m}^{3} / \text { ton }\right)\end{array}$} & \multirow{2}{*}{$\begin{array}{c}\text { Indirect } \\
\text { WF } \\
\left(\mathrm{m}^{3} / \text { ton }\right)\end{array}$} & \multirow[t]{2}{*}{$\begin{array}{c}\mathrm{WF} \\
\left(\mathrm{m}^{3} / \text { ton }\right)\end{array}$} \\
\hline & Green & Blue & Grey & & \\
\hline $\mathrm{Pa}$ & 423.77 & $1,016.13$ & 92.22 & 0.32 & $1,532.44$ \\
\hline $\mathrm{Ch}$ & 635.65 & 18.56 & 131.96 & 0.34 & 786.51 \\
\hline
\end{tabular}

$\overline{\mathrm{Pa}}=$ Pathumthani and $\mathrm{Ch}=$ Chonburi

In reality, the two provinces some similarities climate and season (Table II) but the water footprint is almost double. The irrigation system plays an important role to produce fruit bunches, continuously. Chonburi farmers notice a significant yield between rainy season and dry. Whereas, the season effects could not distinguish their product in Pathumthani. In addition, this research demonstrates the use of irrigation water in excess of Pathumthani. The guidelines for the proper management of water for agriculture, it is also important in the future. Due to the shortage of water is deteriorating steadily. In this case, if the water is properly managed. The excess blue water can be used for agriculture and other industries in order to create more value.

Oil palm is growing popularity in the Southern because the plants need high and consistency amount of water but with good irrigation systems. This enables them to grow oil palm in other regions. With the high value product, Palm oil is a major choice of farmers.

(Table VI) The issue of water scarcity was also concerned in this research by using the water deprivation theory of freshwater consumption [13].

Pathumthani is in Chao Phraya watershed, it have a moderate water stress $(0.339)$ according to Gheewala et al.
[14]. On the other hand, Chonburi has a low index (0.026) with Bang Pakong watershed. After water stress index adjustment, it was found that the water deprivation are $344.42 \mathrm{~m}^{3} /$ ton FFB and $0.48 \mathrm{~m}^{3} /$ ton FFB for Pathumthani and Chonburi, respectively. For sustainability agriculture reason Chonburi is less concerned compare to Pathumthani in term of water availability.

TABLE VI: WATER DEPRIVATION OF FRESH FRUIT BUNCHES IN PATHUMTHANI AND CHONBURI

\begin{tabular}{ccccr}
\hline \hline Area & Watersheds & $\begin{array}{l}\text { Blue WF } \\
\left(\mathrm{m}^{3} / \text { ton }\right)\end{array}$ & WSI & \multicolumn{1}{c}{$\begin{array}{c}\text { Water Deprivation } \\
\left(\mathrm{m}^{3} \mathrm{H}_{2} \mathrm{Oeq} / \text { ton }\right)\end{array}$} \\
\hline \hline $\mathrm{Pa}$ & Chao Phraya & $1,016.13$ & 0.339 & 344.46 \\
$\mathrm{Ch}$ & Bang Pakong & 18.56 & 0.026 & 0.48 \\
\hline \hline
\end{tabular}

$\mathrm{Pa}=$ Pathumthani, $\mathrm{Ch}=$ Chonburi and WSI = Water Stress Index

\section{CONCLUSION}

The study assessed the water footprint of palm oil fresh fruit bunches in Pathumthani and Chonburi, the area that the precipitations are less than $1,800 \mathrm{~mm}$ per year. We found that Pathumthani is more suitable in many perspectives e.g. climate, irrigation system, farm management (fertilizers) but not for water scarcity circumstance.

This research compares blue water from theoretical and field test. When the irrigation existed, Farmers applied a large amount of water in the field more than theory. Even, it could increase more yield. The question on water efficiency is still need an answer. Water management scheme could become important. The adjusted water footprint (water deprivation) shows a concern when integrated with water stress index. Especially, in case we confront with water scarcity and competition between food, feed and energy. In Pathumthani, This area could be also rice fields and orange. In case of Chonburi, the irrigation system is not strongly developed but many farmers plant oil palm to replace other crops. The yield expectation is not be so high but it is still economically reasonable. The appropriate plants should be prioritized in rural development context depend on factors and one of them is water availability resource; to maintain and promote the sustainability development.

\section{ACKNOWLEDGMENT}

Authors thank the department of meteorology, provincial agriculture office and oil palm farmers who gave the information for researches. This study was accomplished through the funding of National Science and Technology Development Agency (NSTDA) Thailand and Faculty of Engineering, Thammasat University.

\section{REFERENCES}

[1] Department of Agricultural Extension, Ministry of Agriculture and Cooperatives. (2009). The furtherance of palm oil production efficiency in the East of Thailand. [Online]. Available: http://www.edoae.doae.go.th/oil\%20palm.htm

[2] United Nations Environment Programme (UNEP), "Water footprint and corporate water accounting for resource efficiency," Korea International Cooperation Agency (KOICA), 2011

[3] A. Y. Hoekstra, A. K. Chapagain, M. M. Aldaya, and M. M. Mekonnen, "Water Footprint Manual State of the Art," Water Footprint Network, Netherlands, 2009. 
[4] S. Pongpinyoparb and T. Mungchareon, "Water Footprint of ethanol from cassava (Thailand)," Kasetsart Engineering Journal, vol. 24, pp. 41-51, 2011.

[5] R. Kongboon and S. Sampattagul, "The water footprint of sugarcane and cassava in northern Thailand," Procedia-Social and Behavioral Sciences, vol. 40, pp. 451-456, 2012.

[6] L. Sukchareon, R. Kongboon, and S. Sampattagul, "Water footprint of Biodiesel from palm oil (Thailand)," in Proc. Sustainable Innovation and Industrial Management Conference, Thailand, 17-18 October, 2012.

[7] A. Y. Hoekstra, Chapagain, A. K. Aldaya, and M. M. Mekonnen, "The Water Footprint Assessment Manual," Water Footprint Network, Netherlands, 2011.

[8] M. S. Babel, B. Shrestha, and S. Perret, "Hydological impact of biofuel production: A case study of the Khlong Phlo Watershed in Thailand," Agricultural Water Management, vol. 101, pp. 8-26, 2011.

[9] ISO 14046 Water Footprint- Principle, Requirements and Guidelines, 2010.

[10] A. D. Martin, "Water footprint of Electric Power Generation: Modeling its use and analyzing options for a water-scarce future," Ph.D. Thesis, Massachusetts Institute of Technology, USA, 2012.

[11] FAO (Food and Agriculture Organization), "Software CROPWAT 8.0 and Example of the use of CROPWAT 8," Development and Management Service, Rome, Italy, 2007.

[12] FAO (Food and Agriculture Organization) Irrigation and Drainage Paper, “Crop Evapotranspiration. Water Resources," Development and Management Service, Rome, Italy, 2006.

[13] S. Pfister, A. Koehler, and S. Hellweg, "Assessing the Environmental Impacts of Freshwater Consumption in LCA," Environ. Sci. Technol., vol. 43, pp. 4098-4104, 2009.

[14] S. H. Gheewala, T. Silalertruksa, P. Nilsalab, R. Mungkung, S. R. Perret, and N. Chaiyawannakarn, "Water footprint and impact of water consumption for food, feed, fuel crops production in Thailand," Water J., vol. 6, pp. 1698-1718, 2014

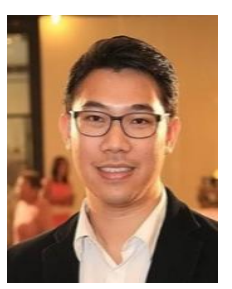

J. Mungkalasiri is a researcher in Life Cycle Assessment Laboratory under the National Metal and Materials Technology Center (Thailand), a holder of Ph.D. degree in material science from University of Toulouse. His expertise is in national life cycle database development $\&$ life cycle management. In the past, he is a member in Developing of Certifying and Verifying Systems of Carbon Footprint for Product \& Organization for Industrial sectors and he also experienced in water footprint.

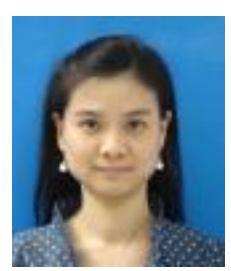

R. Wisansuwannakorn was born in Thailand. As a position engineer, she graduated from Chulalongkorn University, Thailand in M.Sci of biotechnology. She has experiences in carbon footprint of organization \& product, and also manage life cycle database for Thai National LCI database. Her previous interests are in pulp, paper and chemical industry. Now she works for the National Metal and Materials Technology Center (MTEC) Thailand.

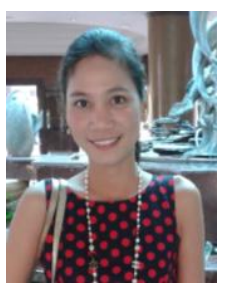

W. Paengjuntuek was born in Thailand. She received the B.Eng. degree in chemical engineering from Khon Kaen University, Thailand in 2004 and the D.Eng. degree in chemical engineering from Chulalongkorn University, Thailand in 2008. Since 2008, she has been a lecturer at the Department of Chemical Engineering, Faculty of Engineering, Thammasat University. Her research fields of interest include process simulation and control, optimization, alternative energy, environmental assessment and their applications in chemical processes. 